\title{
Differential interleukin-1 receptor antagonism on pancreatic beta and alpha cells. Studies in rodent and human islets and in normal rats
}

\author{
U. Zumsteg ${ }^{1}$, J.I. Reimers ${ }^{1}$, F.Pociot ${ }^{1}$, L.Mørch ${ }^{1}$, S.Helqvist ${ }^{1}$, M. Brendel ${ }^{2}$, R. Alejandro ${ }^{2}$, T.Mandrup-Poulsen ${ }^{1}$, \\ C.A. Dinarello ${ }^{3}$,J. Nerup ${ }^{1}$
}

${ }^{1}$ Steno Diabetes Center, Gentofte, Denmark

${ }^{2}$ Diabetes Research Institute, University of Miami School of Medicine, Miami, Florida, USA

${ }^{3}$ Tufts University School of Medicine, Boston, Massachusetts, USA

\begin{abstract}
Summary. The monokines interleukin $-1 \alpha$ and $-\beta$ have been implicated as effector molecules in the immune-mediated pancreatic beta-cell destruction leading to insulin-dependent diabetes mellitus. Here we investigated the effects of interleukin-1. receptor antagonism on insulin and glucagon release of rat, mouse and human islets exposed to recombinant human interleukin-1 $\beta$, and on interleukin- $1 \beta$ induced changes in blood glucose, serum insulin and serum glucagon levels in Wistar Kyoto rats. The interleukin-1 receptor antagonist reduced the co-mitogenic effect of interleukin- $1 \beta$ on mouse and rat thymocytes with a $50 \%$ inhibitory concentration of 10- and 100-fold molar excess, respectively. Complete inhibition was obtained with a 100-1,000-fold molar excess. However, at a 100 -fold molar excess the interleukin-1 receptor antagonist did not antagonise the potentiating effect of interleukin- $1 \beta$ on rat islet insulin accumulation during 3 and $6 \mathrm{~h}$ of exposure or of interleukin- $1 \beta$-induced inhibition of insulin release after $24 \mathrm{~h}$. In contrast, interleukin-1 $\beta$-stimulated islet glucagon release was completely antagonised by a 100 -fold molar excess of interleukin-1 receptor antagonist. A 10,000fold molar excess of interleukin-1 receptor antagonist was needed to antagonise interleukin- $1 \beta$ stimulatory and inhibi-
\end{abstract}

tory effects on rat beta-cell function in vitro. A 100-fold excess of interleukin- 1 receptor antagonist could not counteract interleukin- $1 \beta$ effects on mouse and human beta cells, excluding species difference in the efficacy of the human interleukin-1 receptor antagonist. An anti-mouse interleukin-1 receptor type I antibody completely abolished interleukin$1 \beta$ effects on isolated mouse islets. A $10-100$-fold molar excess of interleukin-1 receptor antagonist antagonised interleukin- $1 \beta$-induced fever, hypercorticosteronaemia and hyperglucagonaemia, but not interleukin- $1 \beta$-induced reduction in insulin/glucose ratio in normal rats. In conclusion, our results suggest that antagonism of interleukin- $1 \beta$ effects on beta cells requires higher concentrations of interleukin-1 receptor antagonist than those necessary to block interleukin-1 action on islet alpha cells and other interleukin- 1 targets in vitro and in vivo. This may contribute to the understanding of the specificity of the immunological beta-cell destruction leading to insulin-dependent diabetes.

Key words: Cytokine, interleukin-1 receptor antagonist, insulin-dependent diabetes mellitus.
Interleukin-1 (IL-1) causes selective cytotoxicity to beta cells in isolated rat islets of Langerhans and in the perfused rat pancreas [1-4] and may be a key effector molecule in the initial phase of the processes leading to insulindependent diabetes mellitus [5-7]. In vivo IL-1 and other cytokines such as tumour necrosis factor (TNF) alpha and IL-6 are expressed by inflammatory cells in the islets of BB-rats and non-obese diabetic (NOD) mice $[8,9]$, and repeated i.p. injections of recombinant human (rh) IL-1 $\beta$ induce hyperglycaemia and hypoinsulinaemia in normal Wistar Kyoto rats [10].

The mechanisms underlying the biological IL-1 effects are not fully understood. Two types of specific cell surface receptors for IL-1 (IL-1 R) have been described [11]. The IL-1 R type I (IL-1 RtI) is a high affinity IL-1 R found on T cells, endothelial cells, keratinocytes, hepatocytes, fibroblasts and epithelial cells. A different IL-1 R gene product exists on bone marrow cells, neutrophils, pre-B cells and macrophage cell lines, termed IL-1 RtII [12]. However, some cells display both types of IL-1 R [12, 13]. Message for IL-1 RtI, but not for IL-1 RtII, is expressed in normal beta cells [14] whereas hamster insulinoma cells express both IL-1 R's $[15,16]$.

An IL-1 specific inhibitor has been described in the urine of patients with monocytic leukaemia [17] and in the supernates of Ig-stimulated human monocytes [18]. Termed the IL-1 "inhibitor", it blocked the binding of IL1 to cells without agonist activity [19]. This IL-1 inhibitor has now been cloned, expressed in Escherichia coli, and the recombinant protein renamed IL-1 receptor antago- 
nist (IL-1 ra) [20] or IL-1 receptor antagonist protein (IRAP)[21]. At $4^{\circ} \mathrm{C}$ it appears to have the same affinity for IL-1 RtI-bearing cells as bona fide IL-1, although 10100 -fold molar excess is usually required to block the biological activity of IL-1 on IL-1 RtI bearing cells in vitro. IL-1 ra also recognises the IL-1 RtII on neutrophils, Blymphocytes and monocytes [22]. Twenty- to 500-fold greater concentrations of IL-1 ra to IL-1 are required to antagonise IL-1RtII-mediated effects in vitro, and the amount require in vivo is clearly higher [23].

Recent studies $[24,25]$ reported that a human IL-1 ra protein is capable of protecting rat beta cells against inhibitory effects of human IL- $1 \beta$ when added in a 10-to 100 fold molar excess. Here we studied the influence of a human IL-1 ra on the effects of rhIL-1 $\beta$ on insulin production in rat, mouse and human pancreatic islets and on glucagon production in rat islets, as well as on rhIL- $1 \beta$-induced changes in body temperature, corticosterone, blood glucose, insulin and glucagon in normal rats.

We report that compared to other cell types including islet alpha cells, islet beta cells require unexpectedly high concentrations of IL- 1 ra in order to block IL-1-induced changes in functional activity. Further, the blocking effect of a monoclonal, neutralizing anti-mouse IL-1 RtI-antibody (IL-1 RtIab) on IL-1-induced effects on mouse islets indicates a pivotal role for IL-1 RtIs for IL-1 signal transduction in pancreatic beta cells.

\section{Materials and methods}

\section{Materials}

One single batch of authentic recombinant human ( $\mathrm{rh}$ ) IL-1 $\beta$ with the correct N-terminal amino-acid at position 117 (alanine) and with physiochemical and biological properties identical to purified natural hIL-1 $\beta$ was used (Novo Nordisk $A / S$, Bagsværd, Denmark). A synthetic gene, $N$-terminally extended with nucleotides encoding for aminoacids Met-Glu-Ala-Glu was expressed in E. coli, and a dipeptidase cleavage was performed during the purification procedure [26]. Compared to the N-terminally extended Met-Glu-Ala-Glu-IL$1 \beta$ form with identical immunoreactivity, the authentic rhIL- $1 \beta$ exerted a 100 -fold higher binding affinity and was 100 -fold more potent than the extended form [26,27]. Specific bioactivity measured in the mouse thymocyte co-stimulatory assay was $400 \mathrm{WHO} \mathrm{U} / \mathrm{ng}$, characterized in relation to the World Health Organisation interim reference rhIL-1 $\beta$ reagent (lot nr. 86/552; National Institute for Biochemical Standards and Control, London, UK). Recombinant human IL-1 receptor antagonist (IL-1 ra) was provided by Dr. R. C. Thompson (Synergen Inc., Boulder, Co., USA) [20]. The purified, monoclonal anti-mouse IL-1 RtIab (35F5) was obtained from Drs. R. Chizzonite and A.Stern (Hoffmann-LaRoche Inc., Nutley, NJ, USA) [28-30]. As control antibody we used a purified rat-antimouse Lyt- 1 antibody. In all islet experiments the IL- 1 ra was added to the culture medium 20-30 min prior to rhIL-1 $\beta$.

\section{Thymocyte co-stimulatory assays}

rhIL- $1 \beta$ bioactivity was determined by the co-mitogenic activity on phytohaemagglutinin (PHA)-stimulated murine thymocytes from 5-week-old male $\mathrm{C} 3 \mathrm{H} / \mathrm{HeN}$ mice (Charles River, Sulzfeld, FRG), as described previously in detail [31]. For interspecies control studies, we developed a rat thymocyte co-stimulatory assay as a modification of the classical mouse thymocyte assay. Briefly, thymocytes were prepared from 5-week-old Wistar Kyoto male rats (Møllegaard, Lille Skensved, Denmark). Thymocytes were washed in RPMI 1640 with Hepes supplemented with $350 \mathrm{mg} / 1$ streptomycin, $0.4 \mathrm{MIU} / \mathrm{l}$ penicillin, $0.8 \mathrm{mmol} / \mathrm{l} \mathrm{L}$-glutamine, and $2.5 \times 10^{-5} \mathrm{~mol} / \mathrm{l} 2$-mercaptoethanol, and $10 \%$ heat-inactivated normal human serum (NHS), and stimulated with $5 \mu \mathrm{g}$ PHA in flat bottomed multidishes and cultured for $72 \mathrm{~h}\left(1 \times 10^{6} \mathrm{cells} / 200 \mu \mathrm{l}\right)$. PHA was chosen since the stimulatory index was approximately $20 \%$ higher than that of concanavalin $\mathrm{A}$ (data not shown). Eight- to 16 two-fold dilutions of rhIL-1 $\beta$ with or without different amounts of IL-1 ra (Table 1 ) were analysed in groups of three or six. ${ }^{3} \mathrm{H}$-thymidine $(1 \mu \mathrm{Ci}$ per well) was added $18 \mathrm{~h}$ before harvest of the cultures. Cells were then harvested on glass filters, and ${ }^{3} \mathrm{H}$-thymidine incorporation was measured by scintillation counting. In all experiments a standard rhIL- $1 \beta$ preparation was included.

\section{Islet isolation and culture}

Rat and mouse islets. Four- to 6-day-old outbred Wistar rats and 20 25-day-old inbred NMRI mice (Møllegaard) were killed by decapitation or dislocation of the neck, respectively. The pancreatic islets were isolated by collagenase digestion as previously described [32, 33]. Islets were pre-cultured for 5-7 days in humidified atmospheric air at $37^{\circ} \mathrm{C}$ in RPMI 1640 (Flow Laboratories, Irvine, UK) with $11 \mathrm{mmol} / \mathrm{l}$ glucose, $20 \mathrm{mmol} / \mathrm{l}$ Hepes buffer, $\mathrm{pH} 7.3,0.1 \mathrm{MIU} / \mathrm{l}$ penicillin, $100 \mathrm{mg} / 1$ streptomycin and $10 \%$ newborn calf serum (NCS). For the 6,24 and 144 h experimental cultures $10 \%$ NCS was replaced by $0.5 \%$ NHS. At $2 \mathrm{~h}$ glucose challenges were performed in KRB containing $0.2 \%$ bovine serum albumin (BSA) and $20 \mathrm{mmol} / \mathrm{l}$ Hepes with either 1.67 or $16.7 \mathrm{mmol} / \mathrm{L}$-glucose. The basal insulin release from the neonatal rat islets increased from $0.15 \pm 0.06 \mathrm{ng} \cdot$ islet $^{-1} \cdot \mathrm{h}^{-1}$ in $1.67 \mathrm{mmol} / \mathrm{l}$ glucose to $4.0 \pm 0.34 \mathrm{ng} \cdot$ islet ${ }^{-1} \cdot \mathrm{h}^{-1}$ in $16.7 \mathrm{mmol} / \mathrm{l}$ glucose $(n=20)$. The basal insulin release from mouse islets increased from $0.13 \pm 0.03 \mathrm{ng} \cdot$ islet $^{-1} \cdot \mathrm{h}^{-1}$ in $1.67 \mathrm{mmol} / 1$ glucose to $0.94 \pm 0.15 \mathrm{ng} \cdot$ islet $^{-1} \cdot \mathrm{h}^{-1}$ in $16.7 \mathrm{mmol} / \mathrm{lglu}-$ cose $(n=7)$. Previous morphological studies showed no non-endocrine cells in a large number of random sections of rat islets pre-cultured for 7 days [1]. Measures that delete non-endocrine islet passenger cells (culture in $95 \%$ oxygen or prolonged preculture) did not protect rat islets against IL-1 toxicity, indicating that presence of passenger cells did not influence IL-1 effects on islet endocrine cells [34].

Human islets. Human islet isolation and culture were carried out in the same laboratory, i.e. University of Miami School of Medicine, Miami, Florida. Human islets were isolated by semi-automated digestion-filtration technique [35] and purified by utilising discontinuous Euro-Ficoll gradients on the COBE 2991 cell-separator [36]. Viability of the isolated islets was ensured by means of a flourescence inclusion/exclusion test [37]. Furthermore, the human islets responded to an acute glucose challenge by an increase in insulin release at $1.67 \mathrm{mmol} / \mathrm{l}$ glucose from $1.81 \pm 0.95 \mathrm{ng} \cdot$ islet $^{-1} \cdot \mathrm{h}^{-1}$ to $4.93 \pm 2.73 \mathrm{ng} \cdot$ islet $^{-1} \cdot \mathrm{h}^{-1}$ at $16.7 \mathrm{mmol} / \mathrm{l}(n=6, p<0.05)$. The mean human islet content of DNA was $49 \pm 2.7 \mathrm{ng} /$ islet $(n=6)$ and the mean insulin content was $12.0 \pm 5.2 \mathrm{ng} /$ islet $(n=6)$. Human islets were cultured as described for rodent islets with the exception that the pre-culture period varied between 24 and $48 \mathrm{~h}$.

\section{Islet capacity for insulin release in response to a 2-h glucose challenge}

Duplicate groups of 50 islets were washed once in KRB containing $1.67 \mathrm{mmol} / \mathrm{l}$ of glucose and then placed in wells containing $0.5 \mathrm{ml}$ of $\mathrm{KRB}$ with $1.67 \mathrm{mmol} / \mathrm{l}$ glucose. After incubation for $1 \mathrm{~h}$ at $37^{\circ} \mathrm{C}$ the medium was removed and replaced by $\mathrm{KRB}$ containing $16.7 \mathrm{mmol} / \mathrm{l}$ glucose. After a 2-h incubation the KRB containing $16.7 \mathrm{mmol} / \mathrm{g}$ glucose was analysed for released insulin by RIA using a rat insulin standard [38] and glucagon by a commercially available RIA kit 
Table 1. Dose-dependent inhibitory effect of interleukin-1 receptor antagonist (IL-1ra) on the co-mitogenic activity of recombinant human interleukin- $1 \beta$ (rhIL-1 $\beta$ ) on phytohaemagglutinin (PHA)stimulated $(5 \mu \mathrm{g} / \mathrm{ml})$ thymocytes

\begin{tabular}{llc}
\hline & $\begin{array}{l}\text { Mitogenic activity on } \\
\text { mouse thymocytes in } \\
\text { cpm (mean } \pm \mathrm{SD})\end{array}$ & $\begin{array}{l}\text { Percent activity } \\
\text { of rhIL-1 } \beta \text { acti- } \\
\text { vity }\end{array}$ \\
\hline rhIL-1 $\beta(150 \mathrm{pg} / \mathrm{ml})$ & $40.993 \pm 1.036$ & 100 \\
IL-1ra $(2 \mu \mathrm{g} / \mathrm{ml})$ & $262 \pm 42$ & 0.6 \\
rhIL-1 $\beta:$ IL-1ra & $39.342 \pm 4.296$ & 96 \\
$1: 1$ & $19.712 \pm 1.129$ & 48 \\
$1: 10$ & $2.005 \pm 441$ & 5 \\
$1: 100$ & Mitogenic activity on & \\
& rat thymocytes in cpm & \\
& (mean $\pm \mathrm{SD})$ & \\
thIL-1 $\beta(150 \mathrm{pg} / \mathrm{ml})$ & $17.554 \pm 1.474$ & 100 \\
IL-1ra $(2 \mu \mathrm{g} / \mathrm{ml})$ & $2 \pm 241$ & 0 \\
rhIL-1 $\beta:$ IL-1ra & & 91 \\
$1: 1$ & $15.983 \pm 1.697$ & 91 \\
$1: 10$ & $16.026 \pm 722$ & 48 \\
$1: 100$ & $8.425 \pm 399$ & 3 \\
$1: 1000$ & $501 \pm 395$ & \\
\hline
\end{tabular}

The IL-1 ra had no agonistic acitivity in concentrations ranging from $1 \mathrm{pg} / \mathrm{ml}$ to $2 \mu \mathrm{g} / \mathrm{ml}$. Each cpm-value represents the mean of at least three experiments each performed in triplicate. In all experiments values are corrected for background, i.e. PHA-induced mitogenic activity (mouse: $759 \pm 254 \mathrm{cpm}$, rat: $1458 \pm 1179 \mathrm{cpm}$ )

(Novo Nordisk A/S). The intra-assay variation for the insulin and the glucagon assays were $1.9 \%$ and $2.6 \%$, respectively, and the interassay variations were $10.6 \%$ and $8.3 \%$, respectively.

\section{In vivo studies}

rhIL-1 $\beta$ and IL-1 ra were diluted in sterile, endotoxin-free $0.9 \%$ $\mathrm{NaCl}$ containing $0.1 \%$ strain-identical rat serum to a final concentration of $0.16 \mu \mathrm{g} / \mathrm{ml}$ or $1.6 \mu \mathrm{g} / \mathrm{ml}$ and $16 \mu \mathrm{g} / \mathrm{ml}$, respectively. Inbred male Wistar Kyoto rats with a body weight of 171-238 g (Møllegaard) were housed under controlled conditions of light, humidity and temperature for 10 days before experimentation. The rats were randomised to one daily injection for 5 days with rhIL-1 $\beta(0.4$ $(n=10)$ or $4.0 \mu \mathrm{g} / \mathrm{kg}(n=8))$ or co-injection of rhIL-1 $\beta(0.4$ $(n=10)$ or $4.0 \mu \mathrm{g} / \mathrm{kg}(n=9))$ and IL-1 ra $(40 \mu \mathrm{g} / \mathrm{kg})$. Control rats were randomised to injections with IL-1 ra $(40 \mu \mathrm{g} / \mathrm{kg}(n=10))$ or vehicle $(n=10(\times 2))$. The rats were fed with standard chow (Altromin; Chr. Petersen A/S, Ringsted, Denmark). Since IL-1 is a potent anorectic, the vehicle-treated rats were pair-fed to the rhIL-1 $\beta$ treated rats in the following way: every morning the amount of food consumed by the rhIL- $1 \beta$-treated rats in the preceding 24 -h period was determined by comparing the weights of the food offered and the residual food. An amount of food equal to the amount consumed by the rhIL- $1 \beta$-treated rats per $\mathrm{g}$ body weight were then offered to the vehicle-treated rats. Injections were administered s. c. in the back of the neck at 09.00 hours. Two hours after injection on the first and the fifth day the rectal temperature was measured by means of an electronic thermometer (Ellab, Copenhagen, Denmark), and $250 \mu \mathrm{l}$ tail-vein blood sample was taken for corticosterone analysis. Ten hours after injection on day 3 and 5, tail-vein blood was taken for blood glucose analysis by a Cobas Mira automatic analyser using the dehydrogenase method. Trunk blood obtained at decapitation was collected $10 \mathrm{~h}$ after injection on day 5 in tubes containing $125 \mu \mathrm{l}$ Aprotinin (20,000 kallikrein-inactivator units $/ \mathrm{ml}$; Bayer AG, Leverkusen, FRG) and $30 \%$ EDTA on ice, centrifuged (4000 rev/min for $10 \mathrm{~min}$ ), and serum was frozen until measurement of insulin and glucagon. The detection limits of the corticosterone, insulin and gluca- gon RIAs (Novo Nordisk A/S) were $250 \mathrm{pg} / \mathrm{ml}, 10 \mathrm{pmol} / \mathrm{l}$ and 50 $\mathrm{pg} / \mathrm{ml}$, respectively. Inter-assay coefficients of variation were $11.5 \%$, $13.1 \%$ and $11.5 \%$, and intra-assay coefficients of variation were $7.9 \%, 11.4 \%$ and $17.0 \%$, respectively.

The animal facilities and care were approved by the Danish $\mathrm{Na}$ tional Health Service and the U.S. Federal Drug Administration.

\section{Statistical analysis}

Results are presented as mean \pm SEM or SD. Wilcoxon's matchedpairs test was used for statistics, and $5 \%$ was chosen as the level of significance.

\section{Results}

\section{IL-1 ra effects in the rat and mouse thymocyte co-stimulatory assay}

In the classic mouse thymocyte co-stimulatory assay as well as on rat thymocytes, IL-1 ra exerted a dose-dependent inhibition of the co-mitogenic effect of rhIL- $1 \beta$ on thymocyte proliferation with an $50 \%$ inhibitory concentration $\left(\mathrm{IC}_{50}\right)$ of 1.5 and $15 \mathrm{ng} / \mathrm{ml}$ on mouse and rat thymocytes, respectively. A 100 -fold molar excess of IL-1 ra completely abolished the rhIL- $1 \beta$ effect on mouse thymocytes whereas a 1,000 -fold molar excess was required on rat thymocytes. IL-1 ra by itself did not affect murine thymocyte proliferation (Table 1 ).

\section{rhIL-1Bantagonism in isolated rat pancreatic islets}

rhIL-1 $\beta$ induced the well-established stimulation of insulin accumulation in the medium after 3 and $6 \mathrm{~h}$ of exposure followed by inhibition after 24 and $144 \mathrm{~h}$. The inhibitory effect of rhIL- $1 \beta$ on insulin release was not caused by

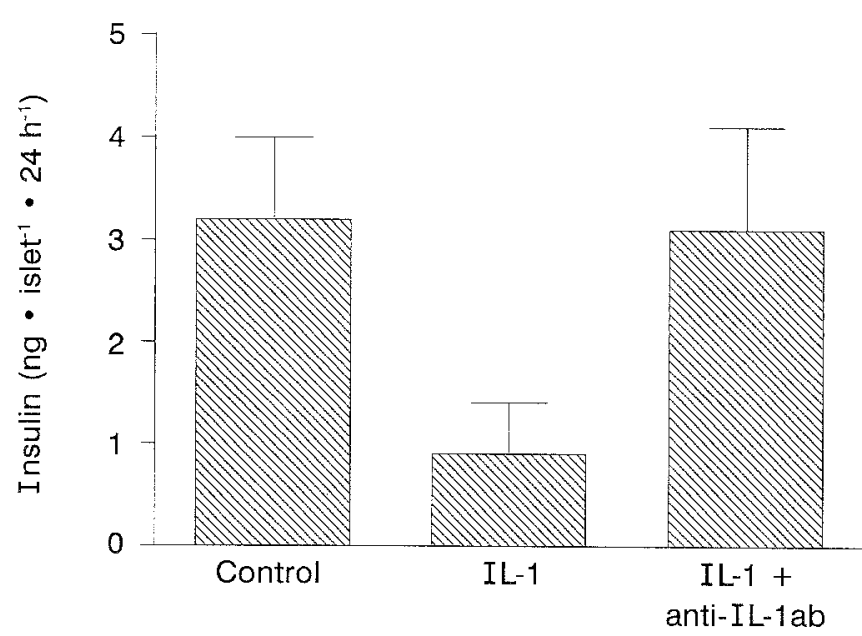

Fig.1. Effects of a rabbit anti-IL- $1 \beta$ antibody $(10 \mu \mathrm{g} / \mathrm{ml})$ on $16.7 \mathrm{mmol} / 1$ glucose-induced insulin release from rat islets after $24 \mathrm{~h}$ rhIL-1 $\beta(150 \mathrm{pg} / \mathrm{ml})$ exposure. rhIL-1 $\beta$-induced functional inhibition of islet insulin release $\left(0.92 \pm 0.58\right.$ vs $3.20 \pm 0.76 \mathrm{ng} \cdot$ islet $^{-1} \cdot 2 \mathrm{~h}^{-1}$ was blocked by anti-IL-1 $\beta$ ab $\left(3.10 \pm 0.92 \mathrm{ng} \cdot\right.$ islet $\left.^{-1} \cdot 2 \mathrm{~h}^{-1}\right)$. Data are mean \pm SEM of duplicate determinations from three independent experiments 
Table 2. Effect of interleukin-1 receptor antagonist (IL-1ra) at a 100-fold molar excess on recombinant human interleukin $1 \beta$ (rhIL-1 $\beta$ ) induced stimulation and inhibition of rat islet insulin accumulation (measured as immunoreactive insulin, IRI) in the medium

\begin{tabular}{lllll}
\hline rhIL-1 $\beta(150 \mathrm{pg} / \mathrm{ml})$ & - & + & + & - \\
IL-1ra $(15 \mathrm{ng} / \mathrm{ml})$ & - & - & + & + \\
Exposure time & IRI (ng/islet) & IRI $(\mathrm{ng} /$ islet $)$ & IRI (ng/islet) & IRI (ng/islet) \\
$3 \mathrm{~h}$ & $1.7 \pm 0.3$ & $4.4 \pm 0.6^{\mathrm{a}}$ & $4.5 \pm 0.6^{\mathrm{a}}$ & $1.8 \pm 0.3$ \\
$6 \mathrm{~h}$ & $3.9 \pm 0.7$ & $8.8 \pm 1.0^{\mathrm{a}}$ & $9.6 \pm 1.2^{\mathrm{a}}$ & $4.0 \pm 0.7$ \\
$144 \mathrm{~h}$ & $158 \pm 13$ & $29 \pm 3^{\mathrm{a}}$ & $35 \pm 3^{\mathrm{a}}$ & $161 \pm 13$ \\
\hline
\end{tabular}

Mean \pm SEM of six independent experiments. ${ }^{a} p<0.05$ vs controls

Table 3. Effect of interleukin-1 receptor antagonist (IL-1ra) at a 10,000-fold molar excess on recombinant human interleukin- $1 \beta$ (rhIL-1 $\beta$ ) induced stimulation and inhibition of rat islet insulin accumulation (measured as immunoreactive insulin, IRI) (6h) and release in response to $16.7 \mathrm{mmol} / 1$ glucose challenge $(24 \mathrm{~h})$

\begin{tabular}{lllll}
\hline $\operatorname{rhIL}-1 \beta(150 \mathrm{pg} / \mathrm{ml})$ & - & + & + & - \\
IL-1ra $(1.5 \mu \mathrm{g} / \mathrm{ml})$ & - & - & + & + \\
Exposure time & IRI $(\mathrm{ng} /$ islet $)$ & IRI $(\mathrm{ng} /$ islet $)$ & IRI (ng/islet) & IRI (ng/islet) \\
$6 \mathrm{~h}$ & $6.9 \pm 0.9$ & $17.8 \pm 1.4^{\mathrm{a}}$ & $7.8 \pm 0.6$ & $7.4 \pm 0.3$ \\
$24 \mathrm{~h}$ & $4.3 \pm 0.4$ & $0.9 \pm 0.1^{\mathrm{a}}$ & $3.9 \pm 0.4$ & $3.9 \pm 0.5$ \\
\hline
\end{tabular}

Mean \pm SEM of six independent experiments. ${ }^{a} p<0.05$ vs controls

additives in the rhIL- $1 \beta$ preparation, because it was blocked by a rabbit anti-iL-1 $\beta$ antibody (Fig. 1). The IL1 ra up to a concentration of $1.5 \mu \mathrm{g} / \mathrm{ml}$ had no agonistic activity on rat islets (Tables 2 and 3 , and data not shown). Neither rhIL-1 $\beta$-induced stimulation over short-term exposure nor inhibition after long-term culture were altered by IL-1 ra at a 100 -fold molar excess (Table 2). After a 24-h rhIL-1 $\beta$ exposure period, the pronounced inhibition of islet insulin release in response to a glucose challenge to $9.8 \%$ of control values was not antagonised by IL-1 ra at a 100-fold molar excess (Fig. 2A). To block the bimodal rhIL-1 $\beta$ effect on rat islets, a 10,000 -fold molar excess of IL-1 ra was required (Table 3 ). A single addition of IL- 1 ra at a 10,000 -fold molar excess completely prevented the long-term (6-day) rhIL-1 $\beta$-induced decrease $(70 \%)$ of islet insulin content (data not shown). In contrast, rhIL$1 \beta$-stimulated glucagon secretion ( $208 \pm 28 \%$ of controls) was reduced by the same 100 -fold molar excess of IL-1 ra $(117 \pm 12 \%$ of controls, $p<0.05)$ (Fig. $2 \mathrm{~B}$ ).

\section{rhIL-1 $\beta$ antagonism in isolated mouse pancreatic islets}

Since the IL- 1 ra seems to be 10 times more potent on mouse thymocytes than on rat thymocytes, the IL-1 ra efficacy was also tested in isolated mouse islets. Exposure of islets to rhIL- $1 \beta(150 \mathrm{pg} / \mathrm{ml})$ for $24 \mathrm{~h}$ increased accumulated islet insulin release (Fig. 3). However, IL-1 ra at a 100-fold molar excess did not antagonise the IL-1 effect. Furthermore, IL-1 $(150 \mathrm{pg} / \mathrm{ml})$ mediated reduction of islet insulin content after $48 \mathrm{~h}$ exposure from $23.2 \pm 3$ to $9.4 \pm$ $0.4 \mathrm{ng} /$ islet $(n=6, p<0.05)$, was not prevented by 100 fold excess of IL-1 ra $(8.8 \pm 0.8 \mathrm{ng} /$ islet $)$.

\section{rhIL-1 $\beta$ antagonism in isolated human islets}

In order to rule out a species restricted effect of the human IL-1 ra on pancreatic islet cells, the effects of the rhIL-1 ra on the rhIL- $1 \beta$-induced inhibition of human beta cells were investigated. Accumulated insulin release from human islets exposed for $6 \mathrm{~h}$ to $150 \mathrm{pg} / \mathrm{ml}$ of rhIL- $1 \beta$ was decreased compared to control $(2.6 \pm 0.7$ and $4.0 \pm 1.2$ $\mathrm{ng} /$ islet, respectively; $p<0.05$ ). Co-incubation with IL-1 ra at a 100 -fold molar excess did not affect the effects of rhIL- $1 \beta(2.8 \pm 0.8 \mathrm{ng} / \mathrm{islet}, p<0.05 \mathrm{vs}$ control $)$. The IL- $1 \mathrm{ra}$ by itself did not effect the accumulated insulin release $(3.7 \pm 0.7 \mathrm{ng} / \mathrm{islet})$. Identical results were seen after $24 \mathrm{~h}$ of exposure with subsequent $16.7 \mathrm{mmol} / 1$ glucose challenge (Fig. 4). Even a 10,000-fold molar excess of IL-1 ra did not counteract rhIL-1 $\beta$ effects on human beta-cells in vitro in one experiment in triplicate (data not shown).

\section{Effect of an $I L-1$ type 1 receptor antibody}

Since the IL-1 ra binds to both IL-1 R type I and IL-1 R type II, we investigated whether specific blockade of the IL-1 RI prevented IL-1 action on islet beta cells. Because the available IL-1 RtIab was mouse-specific, we investigated the effect of the antibody on beta-cell function in mouse islets. In a concentration of $1 \mu \mathrm{g} / \mathrm{ml}$ the IL- $1 \mathrm{RtIab}$ blocked rhIL- $1 \beta$-induced stimulation of insulin release after $24 \mathrm{~h}$ of exposure (control: $8.2 \pm 0.5$, rhIL- $1 \beta$ : 20.3 \pm 0.7, rhIL- $1 \beta+$ IL-1 RtIab: $11.3 \pm 1.4 \mathrm{ng} \cdot$ islet $^{-1} \cdot 24 \mathrm{~h}^{-1}, n$ $=6, p<0.05$ comparing IL-1 to control and to $\mathrm{IL}-1+\mathrm{IL}-1$ RtIab). Reduction of mouse islet insulin content after a 48-h exposure to rhIL- $1 \beta$ (IL-1 $\beta: 9.4 \pm 0.4$, control: $23.2 \pm$ $3.0 \mathrm{ng} /$ islet, $n=6, p<0.05$ ) was abolished by addition of IL-1 RtIab $(20.3 \pm 4.7 \mathrm{ng} /$ islet, $n=6, p<0.05$ vs IL-1, $p=$ NS vs control).

\section{IL-1 ra effects in normal rats}

Subcutaneous injection of $4.0 \mu \mathrm{g} / \mathrm{kg}$ body weight thIL-1 $\beta$ for 3 or 5 days caused hyperglycaemia $(19.4 \pm 3.8$ and $17.4 \pm 5.5 \mathrm{mmol} / 1$, respectively) compared to rats injected with IL-1 ra only and vehicle-treated pair-fed control rats (day 3: $6.0 \pm 0.6$ and $5.3 \pm 0.6 \mathrm{mmol} / 1$, respectively, day $55.8 \pm 0.2$ and $4.9 \pm 0.3 \mathrm{mmol} / \mathrm{l}$, respectively, all $p<0.00005$ ). Co-injection of IL-1 ra at a 10 -fold molar ex- 

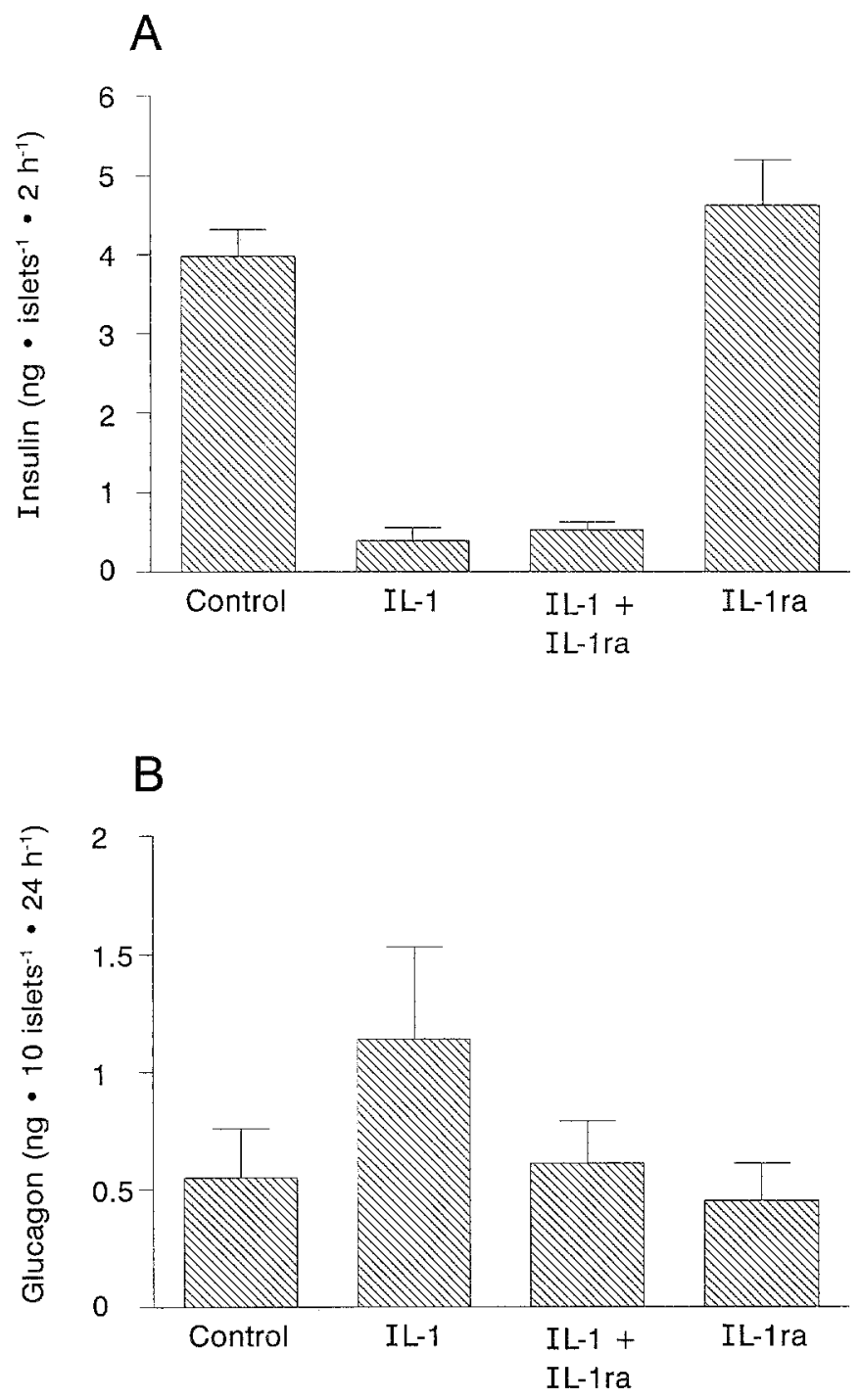

Fig. 2. A Effects of IL-1 ra $(15 \mathrm{ng} / \mathrm{ml})$ on $16.7 \mathrm{mmol} / 1$ glucose-induced insulin release from rat islets after $24 \mathrm{~h}$ rhIL $-1 \beta(150 \mathrm{pg} / \mathrm{ml})$ exposure. The marked decrease of insulin release after rhIL-1 $\beta$ exposure ( $0.39 \pm 0.07$ vs $3.98 \pm 0.34 \mathrm{ng} \cdot$ islet $^{-1} \cdot 2 \mathrm{~h}^{-1}$ in controls $)$ was not prevented by IL- 1 ra at a 100 -fold molar excess over rhIL- $1 \beta$ $\left(0.53 \pm 0.09 \mathrm{ng} \cdot\right.$ islet $\left.^{-1} \cdot 2 \mathrm{~h}^{-1}\right)$. IL-1 ra had no agonist activity. Data are mean \pm SEM of duplicate determinations from six independent experiments, $p<0.05$ vs controls for rhIL-1 $\beta$ and rhIL- $1 \beta+$ IL-1 ra group. B Effects of IL-1 ra $(15 \mathrm{ng} / \mathrm{ml})$ on rat islet glucagon accumulation during $24 \mathrm{~h}$ rhIL- $1 \beta(150 \mathrm{pg} / \mathrm{ml})$ exposure. Glucagon secretion was stimulated by rhIL-1 $\beta(1.14 \pm 0.39$ vs $0.55 \pm 0.21 \mathrm{ng} / 10$ islets $)$. In contrast to the finding in insulin release co-incubation with IL- 1 ra at a 100 -fold molar excess antagonised rhIL- $1 \beta$ stimulated alpha cell function $(0.61 \pm 0.18 \mathrm{ng} / 10$ islets $)$. Data are mean $\pm S E M$ of duplicate determinations from six independent experiments, $p<0.05$ for rhIL$1 \beta$ group, $p=$ NS for rhIL- $1 \beta+$ IL- 1 ra group vs controls

cess over rhIL- $1 \beta$ did not significantly affect the rhIL-1 $\beta$ induced increase in blood glucose on day 3 or day 5 $(20.8 \pm 5.5$ and $16.8 \pm 3.4 \mathrm{mmol} / \mathrm{l}$, respectively). The insulin/blood glucose ratio was similar in the rats treated with rhIL-1 $\beta$ and the rats co-injected with rhIL- $1 \beta+\mathrm{IL}-1$ ra in a 10-fold molar excess (Table 4). In contrast, IL-1 ra reduced the rise in glucagon concentration caused by rhIL- $1 \beta$ to the level of the IL- 1 ra or vehicle-treated control rats (Table 4). The IL-1 ra group had significantly

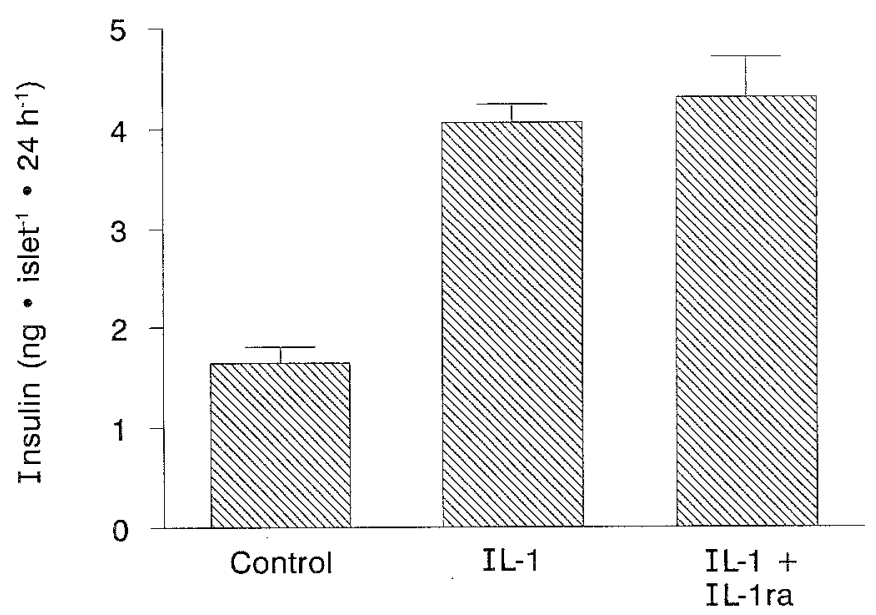

Fig. 3. Effects of IL-1 $\mathrm{ra}(15 \mathrm{ng} / \mathrm{ml})$ on mouse islet insulin accumulation during $24 \mathrm{~h}$ rhIL-1 $\beta(150 \mathrm{pg} / \mathrm{ml})$ exposure. Mouse islets known to be more resistant to rhIL-1 $\beta$ induced functional inhibition showed stimulation of insulin release during $24 \mathrm{~h}$ rhIL-1 $\beta$ exposure which was not antagonised by IL-1 ra at a 100 -fold molar excess. Data are mean \pm SEM of duplicate determinations from six independent experiments. $p<0.05$ vs controls for rhIL $-1 \beta$ and rhIL- $1 \beta+\mathrm{IL}-1$ ra group

higher insulin/blood glucose ratio compared to the vehicle-treated group (Table 4). The insulin/blood glucose ratios cannot be explained by differences in food intake since the vehicle-treated rats were pair-fed to the IL-1treated rats and since co-injection of IL- 1 ra with IL-1 resulted in a food intake similar to the IL-1-treated rats (data not shown). The increased insulin/blood glucose ratio in the IL-1 ra group compared to the vehicle-treated rats can be explained by a significantly higher food intake in the IL-1 ra group compared to the vehicle group (all $p<0.005$, data not shown). The 10 -fold molar excess of IL1 ra was not able to prevent the rhIL- $1 \beta$-induced increases in temperature on day 1 and 5 or corticosterone on day 1 (data not shown), but reduced corticosterone on day 5 (rhIL- $\beta$ vs rhIL- $1 \beta$ and IL-1 ra: $363 \pm 90$ vs $209 \pm 85$ $\mathrm{ng} / \mathrm{ml}, p<0.006)$. However, using the lower rhIL- $1 \beta$ concentration $(0.4 \mu \mathrm{g} / \mathrm{kg})$, a 100 -fold molar excess of IL-1 ra partially counteracted rhIL- $1 \beta$-induced fever (rhIL- $1 \beta$ vs rhIL- $1 \beta$ and IL-1 ra; day $1: 39.6 \pm 0.4$ vs $39.0 \pm 0.2^{\circ} \mathrm{C}$, day 5: $38.8 \pm 0.4$ vs $38.1 \pm 0.2^{\circ} \mathrm{C}$, both $\left.p<0.007\right)$ and serum corticosterone (day 1: $449 \pm 31$ vs $369 \pm 61 \mathrm{ng} / \mathrm{ml}$, day 5 : $314 \pm 73$ vs $154 \pm 44 \mathrm{ng} / \mathrm{ml}$, both $p<0.005)$ but not the rhIL-1 $\beta$-induced hyperglycaemia on day $3(11.8 \pm 3.3$ vs $10.4 \pm 2.4 \mathrm{mmol} / \mathrm{l})$. Injection of $0.4 \mu \mathrm{g} / \mathrm{kg}$ of $\mathrm{rhIL}-1 \beta \mathrm{did}$ not induce changes in blood glucose, serum insulin, or insulin/blood glucose ratio on day 5 .

\section{Discussion}

A recently cloned natural competitive inhibitor of IL-1 binding to its receptors, the IL-1 receptor antagonist, has to date been reported to be able to block all known responses to IL-1 [23]. For example, the antagonist blocks the co-mitogenic effect of IL-1 on thymocytes [19, 39], IL1 -induced prostaglandin $\mathrm{E}_{2}$ production from synovial cells 


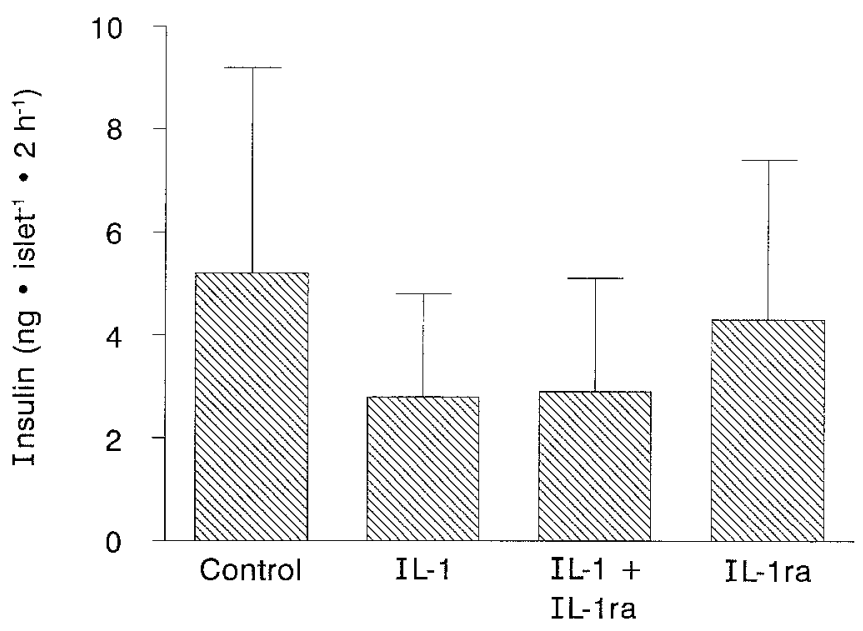

Fig.4. Effects of $\mathrm{LL}-1 \mathrm{ra}(15 \mathrm{ng} / \mathrm{ml})$ on $16.7 \mathrm{mmol} / \mathrm{l}$ glucose-induced insulin release from human islets after $24 \mathrm{~h}$ rhIL- $1 \beta(150 \mathrm{pg} / \mathrm{ml})$ exposure. Insulin release after rhIL- $1 \beta$ exposure was decreased to $2.8 \pm 2.0 \mathrm{vs} 5.2 \pm 4.0 \mathrm{ng} \cdot$ islet $^{-1} \cdot 2 \mathrm{~h}^{-1}$ in controls. Even intra-species the IL- 1 ra at a 100 -fold molar excess did not antagonise rhIL- $1 \beta$-induced functional inhibition $\left(2.9 \pm 2.2 \mathrm{ng} \cdot\right.$ islet $\left.^{-1} \cdot 2 \mathrm{~h}^{-1}\right)$ and did not exert any agonist activity $\left(4.2 \pm 3.2 \mathrm{ng} \cdot \operatorname{islet}^{-1} \cdot 2 \mathrm{~h}^{-1}\right)$. Data are mean \pm SEM of triplicate determinations from six different isolates. $p<0.05$ vs controls for rhIL $-1 \beta$ and thIL $-1 \beta+\mathrm{IL}-1$ ra group, $p=\mathrm{NS}$ for the IL-1 ra group

Table 4. Effect of recombinant human interleukin- $1 \beta(\mathrm{rhIL}-1 \beta)$ and interleukin-1 receptor antagonist (IL-1ra) on insulin/blood-glucose ratio and glucagon concentrations in normal rats

\begin{tabular}{lccl}
\hline Treatment & $n$ & $\begin{array}{l}\text { Insulin/Blood- } \\
\text { glucose ratio } \\
(\mathrm{pmol} / \mathrm{mmol})\end{array}$ & $\begin{array}{l}\text { Glucagon } \\
(\mathrm{pg} / \mathrm{ml})\end{array}$ \\
\hline rhIL-1 $\beta$ & 8 & $7.5 \pm 5.2$ & $259 \pm 58$ \\
rhIL-1 $\beta+\mathrm{IL}-$ & 9 & $10.5 \pm 6.2$ & $198 \pm 50^{\mathrm{a}}$ \\
1ra & & $50.7 \pm 17.8^{\mathrm{b}, \mathrm{c}}$ & $147 \pm 55^{\mathrm{b}}$ \\
IL-1ra & 10 & $25.5 \pm 9.4^{\mathrm{b}}$ & $141 \pm 48^{\mathrm{b}}$ \\
Vehicle & 10 &
\end{tabular}

Rats received one daily injection for 5 days of either rhIL- $1 \beta$ $(4.0 \mu \mathrm{g} / \mathrm{kg}), \mathrm{IL}-1 \mathrm{ra}(40 \mu \mathrm{g} / \mathrm{kg})$, co-injection of rhIL- $1 \beta$ and IL-ra or vehicle. Rats had free access to food except the vehicle-treated rats, which were pair-fed to the rhIL-1 $\beta$-treated rats. Blood was sampled $10 \mathrm{~h}$ after the last injection. Results are given as mean $\pm \mathrm{SD}$ ${ }^{\mathrm{a}} p<0.03,{ }^{\mathrm{b}} p<0.002$ vs IL-1 injected group; ${ }^{\mathrm{c}} p<0.001$ vs vehicle injected group

and collagenase synthesis from chondrocytes [40], IL-1induced endothelial cell neutrophil adhesiveness [21], and IL-1-mediated activation of fibroblast protein kinase [41]. A $50 \%$ inhibition of these IL-1 responses $\left(\mathrm{IC}_{50}\right)$ is achieved with 10-100-fold molar excesses of IL-1 ra over IL-1. Similarly, the IL-1 ra blocks IL-1 mediated fever and hypotension in rabbits with an $\mathrm{IC}_{50}$ of a 100 -fold molar excess $[42,43]$, whereas 10,000 -fold molar excesses are required to block IL-1 induced neutrophilia [30] and nonrapid eye movements and fever elicited by intracerebroventricular injection of IL-1 [44].

Since IL-1 alone or together with other cytokines, i.e. $\mathrm{TNF} \alpha, \mathrm{TNF} \beta$, and interferon- $\gamma$, has been implicated as an early effector of pancreatic islet beta-cell destruction leading to insulin-dependent diabetes $[6,7,45,46]$, it has been tested whether IL- 1 ra was able to prevent rhIL- $1 \beta$-induced beta-cell destruction in vitro and diabetes in animal models. Dayer-Metroz et al. [24] first demonstrated that the suppressive effect of rhIL- $1 \beta$ on insulin release from rat islets could be prevented with urine-derived human IL-1 inhibitor, now known to be identical to the IL-1 ra. The $\mathrm{IC}_{50}$ was a 1:20 dilution of the inhibitor, the molar excess being unknown. Subsequently, Eizirik et al. [25] confirmed these findings with recombinant IL-1 ra. Measuring glucosestimulated insulin release, an $\mathrm{IC}_{50}$ of a 100 -fold molar excess of IL-1 ra over IL-1 was found after exposure of rat islets to rhIL- $1 \beta$ for $1-2 \mathrm{~h}$, and an $\mathrm{IC}_{50}$ of a 1,000 -fold molar excess after exposure for $48 \mathrm{~h}$. Very recently, the IL-1 ra was reported to able to delay the onset of insulin-dependent diabetes in the BB-rat, an animal model for immunemediated insulin-dependent diabetes [47]. It should be noted that the study was not designed to address the question whether the reported effect of IL-1 ra was due to a direct antagonistic effect on IL-1 action on beta cells or to antagonism of the immune adjuvant effect of IL-1.

We found that complete prevention of rhIL- $1 \beta$-mediated stimulation and inhibition of insulin release from rat islets required a 10,000-fold molar excess of IL- 1 ra, whereas rhIL-1 $\beta$-mediated stimulation of glucagon release from rat islets was blocked with a 100-fold molar excess. In addition, a 10-fold molar excess of IL-1 ra was able to abolish rhIL- $1 \beta$-induced glucagon secretion, but not rhIL-1 $\beta$-induced inhibition of beta-cell function in normal rats. These data indicate a striking differential action of the IL-1 ra on islet cells.

The molar excess of IL- 1 ra over rhIL- $1 \beta$ required to block rhIL- $\beta$-induced inhibition of insulin release in vitro was 10 -fold higher when compared to previous studies [25]. This was not due to a lower bioactivity of our IL-1 ra. First, augmented thymocyte proliferation in response to rhIL- $1 \beta$ was inhibited with the expected molar excesses [23]. Secondly, the IL-1 ra blocked rhIL-1 $\beta$-induced glucagon release at a low (100-fold) molar excess. Thirdly, the IL-1 ra attenuated rhIL- $\beta$-induced hypercorticosteronaemia and fever in vivo at the expected molar excess $[21,42]$. There are several possible explanations for the discrepancy in the requirement of IL-1 ra to antagonise IL-1-mediated beta-cell inhibition. Eizirik et al. $[25,48]$ used an rhIL- $1 \beta$ preparation which was 60 - to 6 times less bioactive than native hIL- $1 \beta$ or our authentic rhIL-1 $\beta$ preparation. However, since $10-20 \mathrm{ng} / \mathrm{ml}$ of $\mathrm{IL}-1 \alpha$ (100 U/ng) was antagonised by a 100-fold excess of IRAP makes this possibility less likely. Secondly, Eizirik et al. $[25,48]$ used another type of IL- 1 receptor antagonist i.e. IRAP. Thirdly, the islets in that study were isolated from adult rats, whereas we isolated islets from newborn rats of a different strain. The possibility of age-and strain-dependent differences in glycation of the IL-1 RtI with implications for the affinity of ligand binding cannot be excluded [49].

Species specificity for IL-1, not initially thought to exist, has been reviewed [11]. In analogy, we found that a 10 -fold higher molar excess of IL-1 ra was required to inhibit the co-mitogenic effect of rhIL- $1 \beta$ on rat vs murine thymocytes. These findings suggested that species differences could influence the efficacy of the IL-1 ra. We 
therefore investigated the ability of rhIL-1 ra to inhibit the effect of rhIL- $1 \beta$ on human islets. Data from one experiment indicated that antagonism of the inhibitory effect of IL-1 on human beta cells require more than the 10,000fold excess that we had the practical ability to test. This indicates that a species difference was not the explanation for the high excess of IL-1 ra required for antagonism of IL-1 effects on rat islets.

Previous studies have attempted to identify the major type of IL-1 R expressed by beta cells. In situ hybridization, using probes detecting mRNA, indicated that beta cells in vivo under non-inflammatory circumstances only express IL-1RtI [14]. However, as pointed out in that paper the method used may not detect low copy numbers of mRNA for the IL-1 RtII. Another study investigating IL- $1 \beta$ binding affinity suggested two categories of receptors on a transformed hamster beta-cell line [15], and later mRNA for both IL-1RtI and IL-1 RtII was detected in these cells [16]. Since the IL-1 ra was initially thought only to block the IL-1 RtI, Eizirik et al. [25] suggested that the IL-1 RtI were expressed by beta cells. However, since the IL-1 ra is now known to block both types of IL-1 Rs [12, 22], albeit with different efficacy [12,21], and since some cells have been reported to co-express both IL-1 Rs [12, 13 ], we studied the ability of an anti-mouse-specific IL1 RtI antibody to block rhIL- $1 \beta$ effects on mouse islet beta cells. The complete blocking effect of this antibody, which has been reported [48], suggested either that only IL-1 RtI is present on normal beta cells, that both IL-1Rs are expressed, but the IL-1 RtI is sufficient to transduce the signal, or that both receptors are expressed and required for signal transduction due to receptor co-operativity. Thus, binding of IL-1 to the truncated IL-1 RtII may not in itself lead to signal transduction, but the IL-1/IL-1 RtII may associate with the IL-1/IL-1 RtI, which then transduces the signal via its cytoplasmic portion.

Further studies are needed to clarify if IL-1 is capable of inducing IL-1 RtII expression in normal beta cells and if differences in the ability of the IL-1 ra to antagonise IL-1 action on beta cells vs other islet cells will help to explain the selectivity of beta-cell killing in insulin-dependent diabetes.

Acknowledgements. Ms B. Born, Ms A. del Rio and Ms A. M. Flarup are thanked for technical assistance. The work was supported by the Swiss National Science Foundation (UZ), the Danish Diabetes Association (JIR,TMP), National Institutes of Health Grants No. DK 25802 (MB,RA), DK 07346 (MB,RA) and AI-15614 (CAD), the Diabetes Research Institute Foundation (MB,RA), and Novo Nordisk A/S. JIR is the recipient of a fellowship award from the Foundation of 17-12-1981, SH is the recipient of a postdoctoral research fellowship from the Juvenile Diabetes Foundation International, and $\mathrm{MB}$ is the recipient of a postdoctoral research fellowship from the Deutsche Forschungsgemeinschaft (Br 1179/1-1).

\section{References}

1. Mandrup-Poulsen T, Egeberg J, Nerup J, Bendtzen K, Nielsen JH, Dinarello CA (1987) Ultrastructural studies of time-course and cellular specificity of interleukin-1 mediated islet cytotoxicity. Acta Path Microbiol Immunol Scand 95: C55-C63

2. Sandler S, Bendtzen K, Borg LAH, Eizirik DL, Strandell E, Welsh N (1989) Studies on the mechanisms causing inhibition of insulin secretion in rat pancreatic islets exposed to human interleukin- $1 \beta$ indicate a perturbation in the mitochondrial function. Endocrinology 124: 1492-1501

3. Helqvist S, Zumsteg UW, Spinas GA et al. (1991) Repetitive exposure of pancreatic islets to interleukin- $1 \beta$. An in vitro model of pre-diabetes? Autoimmunity 10: 311-318

4. Wogensen LD, Kolb-Bachofen V, Christensen P et al. (1990) Functional and morphological effects of interleukin $-1 \beta$ on the perfused rat pancreas. Diabetologia 33: 15-23

5. McDaniel ML, Hughes JH, Wolf BA, Easom RA, Turk JW (1988) Description and mechanistic consideration of interleukin1 and insulin secretion. Diabetes 37:1311-1315

6. Mandrup-Poulsen T, Helqvist S, Mølvig J, Wogensen LD, Nerup $J$ (1989) Cytokines as immune effector molecules in autoimmune endocrine diseases with special reference to insulin-dependent diabetes mellitus. Autoimmunity 4: 191-218

7. Sandler S, Eizirik DL, Svensson C, Strandell E, Welsh M, Welsh N (1991) Biochemical and molecular actions of interleukin-1 on pancreatic $\beta$-cells. Autoimmunity $10: 241-253$

8. Jiang Z, Woda BA (1991) Cytokine gene expression in the islets of the diabetic Biobreeding/Worcester rat. J Immunol 146: 29902994

9. Held W, MacDonald HR, Weissman IL, Hess MW, Mueller C (1990) Genes encoding tumor necrosis factor $\alpha$ and granzyme A are expressed during development of autoimmune diabetes. Proc Natl Acad Sci USA 87: 2239-2243

10. Wogensen L, Reimers J, Nerup J et al. (1992) Repetitive in vivo treatment with human recombinant interleukin- $1 \beta$ modifies beta-cell function in normal rats. Diabetologia 35:331-339

11. Dinarello CA (1991) Interleukin-1 and interleukin-1 antagonism. Blood 77: 1627-1652

12. McMahan CJ, Slack JL, Mosley B et al. (1991) A novel IL-1 receptor, cloned from B cells by mammalian expression, is expressed in many cell types. EMBO J 10: 2821-2832

13. Benjamin D, Dower SK (1990) Human B cells express two types of interleukin-1 receptors. Blood 75: 2017-2023

14. Deyerle KL, Sims JE, Dower SK, Bothwell MA (1992) Pattern of IL-1 receptor gene expression suggests role in noninflammatory processes. J Immunol 149: 1657-1665

15. Hammonds P, Beggs M, Beresford G, Espinal J, Clarke J, Mertz $\mathrm{RJ}(1990)$ Insulin-secreting $\beta$-cells possess specific receptors for interleukin-1 $\beta$. FEBS Lett 261: 97-100

16. Eizirik DL, Björklund A, Welsh N (1993) Interleukin-1-induced expression of nitric oxide synthase in insulin-producing cells is preceded by $\mathrm{c}$-fos induction and depends on gene transcription and protein synthesis. FEBS Lett 317: 62-66

17. Belavoine JF, De Rochemonteix B, Williamson K, Seckinger P, Cruchaud A, Dayer JM (1987) Prostaglandin $E_{2}$ and collagenase production by fibroblasts and synovial cells is regulated by urinederived human interleukin 1 and inhibitor(s). J Clin Invest 78: $1120-1124$

18. Arend WP, Joslin FG, Massoni PJ (1985) Effects of immune complexes on production by human monocytes of interleukin 1 or an interleukin 1 inhibitor. J Immunol 134: 3868-3875

19. Seckinger P, Lowenthal JW, Williamson K, Dayer J-M, MacDonald $R$ (1987) A urine inhibitor of interleukin 1 activity that blocks ligand binding. J Immunol 139: 1546-1549

20. Eisenberg SP, Evans RJ, Arend WP et al. (1990) Primary structure and functional expression from complementary DNA of a human interleukin-1 receptor antagonist. Nature 343: $341-346$

21. Carter DB, Deibel MR Jr, Dunn CJ et al. (1990) Purification, cloning, expression and biological characterization of an interleukin-1 receptor antagonist protein. Nature 344: 633-638

22. Granowitz EV, Clark BD, Mancilla J, Dinarello CA (1991) Interleukin-1 receptor antagonist competitively inhibits the binding of interleukin-1 to the type II interleukin-1 receptor. J Biol Chem 266: $14147-14150$

23. Dinarello CA, Thompson RC (1991) Blocking IL-1: interleukin 1 receptor antagonist in vivo and in vitro. Immunology Today 12 : $404-410$ 
24. Dayer-Metroz M-D, Wollheim CB, Seckinger P, Dayer J-M (1989) A natural interleukin 1(IL-1) inhibitor counteracts the inhibitory effect of IL-1 on insulin production in cultured rat pancreatic islets. J Autoimmunity 2: 163-171

25. Eizirik DL, Tracey DE, Bendtzen K, Sandler S (1991) An interleukin-1 receptor antagonist protein protects insulin-producing beta cells against suppressive effects of interleukin- $1 \beta$. Diabetologia 34: 445-448

26. Dalbøge H, Bayne S, Christensen T, Hejnas KR (1989) Cloning and expression of an interleukin- $1 \beta$ precursor and its conversion to interleukin-1 $\beta$. FEBS Lett 246: 89-93

27. Hejnæs KR, Sehested B, Worsaae H, Mølvig J, Wollmer A (1990) The effect of $\mathrm{N}$-terminal extension on the structure and function of human interleukin-1 $\beta$. Biol Chem Hoppe-Seylor 371: 23-30

28. Chizzonite R, Truitt T, Kilian PL et al. (1989) Two high-affinity interleukin 1 receptors represent separate gene products. Proc Natl Acad Sci USA 86: 8029-8033

29. Bomsztyk K, Sims JE, Stanton TH et al. (1989) Evidence for different interleukin 1 receptors in murine B- and T-cell lines. Proc Natl Acad Sci USA 86: 8034-8038

30. McIntyre KW, Stepan GJ, Kolinsky KD et al. (1991) Inhibition of Interleukin 1 (IL-1) binding and bioactivity in vitro and modulation of acute inflammation in vivo by receptor antagonist and anti-IL-1 receptor monoclonal antibody. J Exp Med 173: 931-939

31. Mølvig J, Baek L, Christensen P et al. (1988) Endotoxin-stimulated human monocyte secretion of interleukin 1, tumour necrosis factor alpha, and prostaglandin $\mathrm{E}_{2}$ shows stable interindividual differences. Scand J Immunol 27: 705-716

32. Brunstedt J, Nielsen JH, Lernmark $\AA$, Hagedorn Study Group (1984) Isolation of islets from mice and rats. In: Larner J, Pohl SL (eds) Methods in diabetes research laboratory methods. Vol 1, pt. C. Wiley, New York, pp 254-258

33. Spinas GA, Hansen BS, Linde $S$ et al. (1987) Interleukin 1 dosedependently affects the biosynthesis of (pro)insulin in isolated rat islets of Langerhans. Diabetologia 30:474-480

34. Mandrup-Poulsen T, Spinas GA, Prowse SJ et al. (1987) Islet cytotoxicity of interleukin-1: influence of culture conditions and islet donor characteristics. Diabetes 36: 641-647

35. Tzakis AG, Ricordi C, Alejandro R et al. (1990) Pancreatic islet transplantation after upper abdominal exenteration and liver replacement. Lancet 336: 402-405

36. Ricordi C, Lacy PE, Finke EH, Olack BJ, Scharp DW (1988) Automated method for isolation of human pancreatic islets. Diabetes 37: 413-420

37. London NJM, Contractor H, Lake SP, Aucott GC, Bell PRF, James RFL (1989) A microflurometric viability assay for isolated human and rat islets of Langerhans. Diabetes Res 12:141-149
38. Heding LG (1972) Determination of total serum insulin (IRI) in insulin-treated diabetic patients. Diabetologia 8: 260-266

39. Arend WP, Joslin FG, Thompson RC, Hannum CH (1989) An IL-1 inhibitor from human monocytes. Production and characterization of biologic properties. J Immunol 143: 1851-1858

40. Arend WP, Welgus HG, Thompson RC, Eisenberg SP (1990) Biological properties of recombinant human monocyte-derived interleukin 1 receptor antagonist. J Clin Invest 85: 1694-1697

41. Dripps DJ, Brandhuber BJ, Thompson RC, Eisenberg SP (1991) Interleukin-1 (IL-1) receptor antagonist binds to the 80-KDa IL1 receptor but does not initiate IL-1 signal transduction. J Biol Chem 266: 10331-10336

42. Ikejima T, Zhang X, Dinarello CA (1991) IL-1 receptor antagonist (IL-1 ra) reduces IL-1-mediated fever in the rabbit but not LPS or staphylococcus epidermidis-induced fever. Clin Res 39 : $462 \mathrm{~A}$ (Abstract)

43. OhIsson K, Björk P, Bergenfeldt M, Hageman R, Thompson RC (1990) Interleukin-1 receptor antagonist reduces mortality from endotoxin shock. Nature 348: 550-552

44. Opp MR, Krueger JM (1991) Interleukin 1-receptor antagonist blocks interleukin 1-induced sleep and fever. Am J Physiol 260: R453-R457

45. Campbell IL, Iscaro A, Harrison LC (1988) IFN- $\gamma$ and tumor necrosis factor- $\alpha$. Cytotoxicity to murine islets of Langerhans. J Immunol 141: 2325-2329

46. Pukel C, Baqurizo H, Rabinovitch A (1988) Destruction of rat islet cell monolayers by cytokines. Synergistic interactions of interferon-gamma, tumor necrosis factor, lymphotoxin, and interleukin 1. Diabetes 37: 133-136

47. Dayer-Metroz M-D, Duhamel D, Rufer N at al. (1992) IL-1 receptor antagonist delays spontaneous autoimmune diabetes in BB rats. Eur J Clin Invest 22: A50 (Abstract)

48. Eizirik DL, Tracey DE, Bendtzen K, Sandler S (1992) Role of receptor binding and gene transcription for both the stimulatory and inhibitory effects of interleukin -1 in pancreatic $\beta$-cells. Autoimmunity 12: 127-133

49. Mancilla J, Ikejima I, Clark BD, Orencole SF, Sirko S, Dinarello CA (1989) Lectin binding suggests different glycosylation patterns of IL-1 receptors on different cells. Cytokine 1: 95 (Abstract)

Received: 7 December 1992 and in final revised form: 26 March 1993

Dr. J. Nerup

Steno Diabetes Center

2 Niels Steensensvej

DK-2820 Gentofte

Denmark 